\title{
SERUM ANTI-TRYPTASE IN CHRONIC RHEUMATIC DISEASE
}

\author{
BY \\ HARRY COKE \\ From the Research Laboratories, Charterhouse Rheumatism Clinic, London
}

(RECEIVED FOR PUBLICATION AUGUST 7, 1948)

Holmes and others (1935) reported an anti-tryptic activity of synovial fluid from cases of chronic rheumatic arthritis. The alarm reaction of Selye (1946) introduces an initial shock phase, associated with the production of adrenaline and plasmin (causing fibrinolysis: Macfarlane and Biggs, 1946), and a second phase of counter shock with a developing and increasing resistance to the repetition of the same shock-producing stimulus. The resistance evidenced as anti-plasmin is thought to be possibly identical with anti-trypsin (Biggs and others, 1947). The group of shock-producing stimuli includes severe exercise, emotional - states, and trauma, which are commonly associated with the prerheumatic histories.

Anti-trypsin activity has been known to be a function of serum for many years (Hildebrandt, 1893). The quantitative evaluation of this antiprotease activity of the serum in relation to the activity and extent of the chronic rheumatic arthritis appeared, therefore, likely to be of value.

Trypsin is a peptidase, active at an optimum $p \mathrm{H}$ of $8 \cdot 1$, and otherwise it may be shown to conform to normal enzymatic behaviour and laws. While in the test-tube experiment a casein substrate has usually been employed, trypsin was, in this instance, allowed to digest as a substrate the serum proteins themselves, and the extent of the digestion was measured by estimating the substrate as precipitable proteins before and after digestion. An accurate micro-method for this estimation was both available and convenient for large numbers. A second estimation was made on each serum after extraction with ether, which either as ether or chloroform has long been known to "remove" or " destroy" the anti-tryptase effect.

\section{Technique}

Solutions

1. Phosphate Buffer.-Potassium dihydrogen phosphate, $1 \cdot 3609$ g., was dissolved in $9 \cdot 48 \mathrm{ml}$. N/1 sodium hydroxide and distilled water added to a volume of $200 \mathrm{ml}$.
2. Phenol.-Phenol, $1 \cdot 25 \mathrm{~g}$., was dissolved in $100 \mathrm{ml}$. 0.85 per cent. sodium chloride (a strength which, on dilution, was found to be bacteriostatic and of minimal effect on tryptic digestion).

3. Trypsin.-Allen and Hanbury liquor trypsin co. was used.

4. Precipitating Reagent.- $\mathrm{N} / 10$ sodium orthovanadate (B.D.H.), $36 \mathrm{ml}$., was made up to a volume of $200 \mathrm{ml}$. with $\mathrm{N} / 10$ acetic acid.

\section{Methods}

The method used was to shake thoroughly and vigorously $0.6 \mathrm{ml}$. of serum to be tested with an equal volume of pure ether, which was then corked and left in an upright position for at least one hour. . The lower serum layer was removed with a capillary pipette and placed in an incubator $\left(37^{\circ} \mathrm{C}\right.$.) for one hour. It was left to cool to room temperature. Two tubes of digestion mixtures were put up as follows :
(1) $3.6 \mathrm{ml}$. buffer
$0.7 \mathrm{ml}$. phenol
$0.4 \mathrm{ml}$. trypsin
$0.3 \mathrm{ml}$. normal serum
(2) $3.6 \mathrm{ml}$. buffer
$0.7 \mathrm{ml}$. phenol
$0.4 \mathrm{ml}$. trypsin
$0.3 \mathrm{ml}$. ether-extracted serum

These were mixed thoroughly, and $0.4 \mathrm{ml}$. taken from each ; $1.0 \mathrm{ml}$. precipitating reagent was then added to each separately. They were mixed thoroughly and left to stand at least one hour, then centrifuged for ten minutes at approximately 2,500 r.p.m., and the supernatant decanted and drained. After this the remaining precipitate was dissolved in $2.0 \mathrm{ml}$. N/100 sodium hydroxide. The concentration of protein-vanadate mixture was then measured by estimating the refractive index (although this may be done by many other methods). Both interferometer cells were filled with $N / 100$ sodium hydroxide and the zero reading taken. The test solution was put into one cell, and the result given as the reading minus the zero reading.

The remainder of tubes 1 and 2 were put into an incubator $\left(37^{\circ}\right.$ C. $)$ for exactly twenty-four hours, then cooled to room temperature and $0.4 \mathrm{ml}$. removed from each to estimate proteins again as above.

A concentration of serum protein of $0.972 \mathrm{~g}$. per $100 \mathrm{ml}$. is equivalent to 100 interferometric units. Results are expressed throughout this paper as number of interferometric units.

The difference between the protein substrate in tube 1 
TABLE 1

DEFINITION OF GROUP NUMBERS

\begin{tabular}{|c|c|c|c|c|c|}
\hline \multirow{2}{*}{ Clinical group } & \multicolumn{5}{|c|}{ Numerical group } \\
\hline & 1 & 2 & 3 & 4 & 5 \\
\hline $\begin{array}{l}\text { Normal and non-rheumatic ... } \\
\text { Non-articular rheumatism } \\
\text { Osteo-arthritis }\end{array}$ & $\begin{array}{l}\mathbf{x} \\
\mathbf{x} \\
= \\
= \\
= \\
=\end{array}$ & $\begin{array}{l}\bar{X} \\
\mathbf{X} \\
\overline{-} \\
\bar{X} \\
\bar{X}\end{array}$ & $\begin{array}{l}\bar{X} \\
\mathbf{X} \\
\overline{\bar{X}} \\
\mathbf{X} \\
\mathbf{X}\end{array}$ & $\begin{array}{l}- \\
\mathbf{X} \\
\mathbf{X} \\
\mathbf{X} \\
\mathbf{X} \\
\mathbf{X} \\
\end{array}$ & $\begin{array}{l}\bar{Z} \\
\overline{\mathbf{x}} \\
\mathbf{X} \\
\mathbf{X} \\
\mathbf{X}\end{array}$ \\
\hline
\end{tabular}

before and after digestion gives the figure "A". The difference between the protein substrate after digestion of tube 1 and 2 gives the figure " $B$ ".

Two figures were thus available. In the first place, figure $A$, the degree of digestion of the serum proteins by a standard quantity of trypsin. Secondly, the figure $B$, the difference between the effective digestion of a standard quantity of trypsin upon natural serum and the same specimen after the removal of the anti-tryptic effect by ether.

\section{Results}

Two hundred consecutive cases were examined by this technique, and in order to assess the results on a statistical basis each case had to be placed from a clinical assessment into a definite group represented by " a number". Five group numbers were defined as in Table 1. These figures are based essentially on the extent and activity of the arthritis ; the lower-group numbers referring to more chronic and local conditions and the higher figures to generalized fulminating type of polyarthritis.

Without detailing all the individual results, the tabulated survey of the total results (Table 2) provides the essential features from which statistical evidence may be deduced.

Assuming the practical reality of the grouping, the correlation coefficient for the " $A$ " figures is +0.56 ; and for the " $B$ " figures +0.62 , which are respectively 7.84 and 8.75 times the standard error of the coefficient 0.07 . According to the clinical grouping, arthritis as such occurs in groups 3 , 4, and 5, while groups 1 and 2 are essentially non-articular. The values separating these two sections are thus for $A 41$ and for $B 7 \cdot 0$. The consistency of a figure less than 41 in section $A$ and more than 7.0 in section $B$ with an arthritic condition can be assessed with a simple chi-square test. There were 175 cases where radiological and other proof of arthritis or the reverse was available, and after eliminating cases of spondylitis ankylopoetica and of gout :

\begin{tabular}{c|c|c|c|c}
\hline & \multicolumn{2}{|c|}{ Figure A } & \multicolumn{2}{c|}{ Figure B } \\
\cline { 2 - 5 } & $\begin{array}{c}\text { Below } \\
41\end{array}$ & $\begin{array}{c}\text { Above } \\
41\end{array}$ & $\begin{array}{c}\text { Above } \\
7 \cdot 0\end{array}$ & $\begin{array}{c}\text { Below } \\
7 \cdot 0\end{array}$ \\
\hline $\begin{array}{c}\text { No. of cases of arth- } \\
\text { ritis . . . }\end{array}$ & 77 & 22 & 78 & 20 \\
$\begin{array}{c}\text { No. of cases of non- } \\
\text { articular rheumatism }\end{array}$ & 35 & 41 & 35 & 42 \\
\hline
\end{tabular}

The Chi-square value for these tables is $16 \cdot 14$ and $20 \cdot 5$, so that the value of $P$ is much less than 0.001 in each case. The possibility that these

TABLE 2

SURVEY OF GROUPS

\begin{tabular}{|c|c|c|c|c|c|c|c|c|c|}
\hline \multirow{3}{*}{ Group } & \multirow{3}{*}{$\begin{array}{l}\text { No. of } \\
\text { cases }\end{array}$} & \multicolumn{4}{|c|}{ Figure A } & \multicolumn{4}{|c|}{ Figure B } \\
\hline & & \multirow[t]{2}{*}{$\begin{array}{l}\text { Mean value } \\
\text { of group }\end{array}$} & \multirow{2}{*}{\multicolumn{3}{|c|}{\begin{tabular}{c|c} 
Standard & Standard error \\
of mean \\
deviation \\
oftandard error \\
between two \\
means
\end{tabular}}} & \multirow[t]{2}{*}{$\begin{array}{l}\text { Mean value } \\
\text { of group }\end{array}$} & $\begin{array}{l}\text { Standard } \\
\text { deviation }\end{array}$ & \multirow{2}{*}{\multicolumn{2}{|c|}{$\begin{array}{l}\begin{array}{l}\text { Standard error } \\
\text { of mean }\end{array} \\
\text { ird error } \\
\text { en two } \\
\text { eans }\end{array}$}} \\
\hline & & & & & & & $\begin{array}{c}\text { Sta1 } \\
\text { be }\end{array}$ & & \\
\hline 1 & 23 & $44 \cdot 22$ & $7: 84$ & & $1 \cdot 64$ & $4 \cdot 15$ & $3 \cdot 69$ & 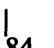 & $0 \cdot 77$ \\
\hline 2 & 47 & $43 \cdot 53$ & $6 \cdot 50$ & & 0.95 & $6 \cdot 55$ & $3 \cdot 39$ & & 0.50 \\
\hline 3 & 43 & $37 \cdot 90$ & $7 \cdot 81$ & & $1 \cdot 19$ & $10 \cdot 45$ & $5 \cdot 33$ & & $0 \cdot 81$ \\
\hline 4 & 36 & $37 \cdot 44$ & 6.98 & & $1 \cdot 16$ & $10 \cdot 70$ & $5 \cdot 37$ & & 0.89 \\
\hline 5 & 51 & $32 \cdot 07$ & 8.99 & & $1 \cdot 26$ & $16 \cdot 05$ & $7 \cdot 63$ & & 1.07 \\
\hline
\end{tabular}


FIGURE.

A.

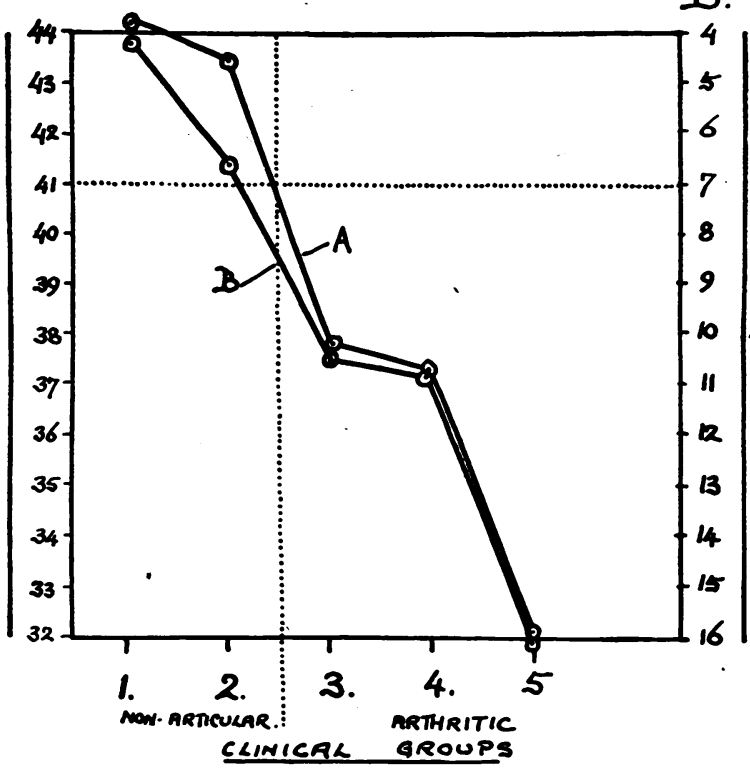

Figure.-The anti-tryptase function of the serum in relation to clinical groups of chronic rheumatic disease.

results occurred thus by fortuitous chance is, therefore, very small.

\section{Comment}

These figures produce evidence that the extension and activity of rheumatic arthritis is accompanied by an increase in an anti-tryptase function of the serum. This relation is clearly demonstrated in graphical form (see Figure). The mean average figures of groups of clinical entities are treated statistically and demonstrate the significant changes in such groups of reasonable numbers. While this is an actuality, it is unreasonable to suppose that each individual case will give a figure exactly corresponding to the mean of the group. Nevertheless, the clinical use of such figures in a much greater number of cases has frequently proved useful as a diagnostic item. It is interesting to note that in respect of the anti-tryptase activity the group of spondylitis ankylopoetica generally tend to give strongly arthritic figures, while gout usually demonstrates negative or normal figures. Fluids from rheumatic bursae or joints give extremely high positive figures.

If the anti-tryptase function can be accepted, it may then be deduced that the increase in antitryptase in arthritic states will have an association with $(a)$ an increase in an anti-tryptic substance; (b) the absence of a normal tryptokinetic substance ; or (c) a modification in the format of the substrate.

In this latter respect the albumin-globulin ratios, which may be altered in rheumatic states, have to be considered and the fact that natural globulins are not so readily digested by trypsin (Bernheim and others, 1942). There is also the possible presence of a combined-protein complex as derived from mathematical deductions by Harkness and Whittington (1947) and akin to the "X-Protein " of Pedersen (1945) and several others. The hypothesis of a combined protein complex is derived partly from the viscometric measurement of the serum. The viscosity of the serum and plasma in chronic rheumatic disease (Cowan and Harkness, 1947) is reported as an important clinical estimation, but it has not been found to correlate at all closely with the anti-tryptic function of the serum. Finally, Ungar (1945) has produced evidence that the antitryptase was a function of splenic activity in that his substance ("splenin-A") increases the rate of association between trypsin and serum anti-tryptase. Reviews of his work (Brit. med. J., 1947 ; Lancet, 1948) and his own review (Ungar, 1947) postulates the anti-tryptase function as being due to two separate individual factors soluble in ether and aqueous solutions respectively. "The question at once arises whether splenin is the normal activator of the anti-trypsin present in the serum."

As the anti-tryptase function of the serum bears a quantitative relationship to the severity of the arthritic process, the association of this function with the physiological experiments of Ungar forms a basis to bring the question of splenic activity with that of the adrenal cortex, the pituitary, and vitamin $\mathrm{C}$ into closer relationship with the chronic rheumatic disorders. These have thus an association also as organic physiological reactions to emotional stimuli suggested by the work of Selye (1946) and Biggs and others (1947). The inactivation of trypsin enzymes by a low oxidation-reduction potential or the "reducing capacity" of the digest mixtures (Grob, 1946) suggests an association of these results with such substances as cysteine in the chronic rheumatic disorders and becomes allied with such therapeutic methods blocking the di-sulphydryl groups of enzymes by heavy metals (Ragan and Boots, 1947).

\section{Summary}

1. A technique is described for a quantitative estimation of the anti-tryptase capacity of serum.

2. The results of such estimations in 200 cases of chronic rheumatic disease are tabulated and analysed. 
3. A quantitative relationship between the antitryptase level of the serum and the extent and activity of the rheumatic arthritic condifion is derived.

4. The relationship of this anti-tryptase capacity with the functional activity of the spleen, pituitary, and adrenal cortex is discussed.

My acknowledgement is due, with thanks for technical assistance, to Miss Marjorie Holt for much of the practical laboratory work.

\section{REFERENCES}

Annotation. (1947). Brit. med. J., 1, 458.

Annotation. (1948). Lancet, 1, 334.

Bernheim, F., Neurath, H., and Erickson, J. O. (1942). J. Biol. Chem., 144, 259.

Biggs, R., Macfarlane, R. G., and Pilling, J. (1947). Lancet, 1, 402.

Cowan, I. C., and Harkness, J. (1947). Brit. med. J., $2,686$.

Grob, D. (1946). J. Gen. Physiol., 29, 219.

Harkness, J., and Whittington, R. B. (1947). Anal. Chim. Acta, 1, 153.

Hildebrandt, H. (1893). Virchows Arch., 131, 5.
Holmes, W. F., Keefer, C. S., and Myers, W. K. (1935). J. clin. Invest., 14, 124, 130.

Macfarlane, R. G., and Biggs, R. (1946). Lancet, 2, 862 . Pedersen, K. O. (1945). "Ultracentrifugal Studies on Serum and Serum Fractions". Uppsala.

Ragan, C., and Boots, R. H. (1947). J. Amer. med: Ass., $133,752$.

Selye, H. (1946). J. clin. Endocrinol., 6, 117.

Ungar, G. (1945). Endocrinol., 37, 329.

- (1947). J. Physiol. Path. gen.. 39, 219.

Pouvoir Anti-tryptique du Sérum dans le Rhumatisme $\tilde{c}$

Chronique

Résumé

1. L'auteur décrit une méthode de détermination ${ }^{\bar{\omega}}$ quantitative du pouvoir anti-tryptique su sérum. II présente sous forme de tableaux et analyse les résultats? de ces déterminations dans deux cents cas de rhumatisme in chronique. Il déduit une relation quantitative entre le? taux d'anti-trypsine sérique et l'étendue et l'activité de $\mathcal{G ~}^{\omega}$ l'arthrite rhumatismale. Il discute le rapport entre ce pouvoir anti-tryptique et l'activité fonctionnelle de la rate, de l'hypophyse et du cortex surrénal. 